\title{
Variation in seed mineral elements profile and yield in field bean (Vicia faba L. var. minor) genotypes
}

\author{
Sara Lombardo, Gaetano Pandino, Gaetano Roberto Pesce, Umberto Anastasi, \\ Rosalena Tuttobene, Giovanni Mauromicale \\ Department of Agriculture, Food and Environment, University of Catania, Italy
}

\begin{abstract}
Field bean (Vicia faba L. var. minor) is one of the major leguminous crops cultivated in the world and mainly destined for animal feed. Although its seed is generally recognised as a good protein source, little is known about its mineral elements profile, which is an important aspect for a balanced animal diet. Therefore, the aim of the present work was to assess the seed mineral elements composition, along with some key production parameters, in eight field bean genotypes grown in a Mediterranean environment, without intensive management, over two years (2009/10 and 2010/11). Independently of the year, the seed of Chiaro di Torre Lama was the richest in phosphorus (P), magnesium, calcium and iron contents, while that of Sint 6 and Motta Chiaro 69 were the most effective accumulators of potassium and zinc, respectively. While all the genotypes yielded better in the second year (with more rainfall), the seasonal effect on seed mineral elements composition depended on the genotype. Indeed, the P content was $46 \%$ lower in Chiaro di Torre Lama, Motta Chiaro 69 and Sint 6 in the second year, while there was only a negligible seasonal effect for Sint 8 with respect to Fe content. Overall, this crop is reasonably productive under a low management regime and its seed can supply significant amounts of certain minerals (particularly P) in feed formulations. Both aspects are important in a perspective of optimising field bean production in the Mediterranean area and, hence, improving farmers' income.
\end{abstract}

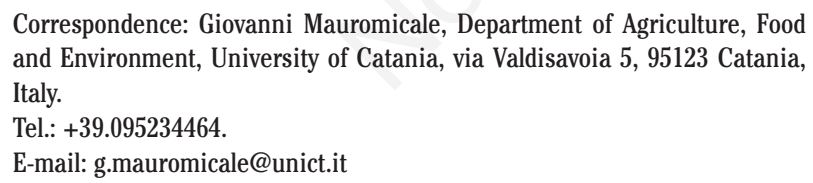

Key words: Field bean; genotype; grain yield; growing season; low management regime; seed mineral elements composition.

Received for publication: 29 March 2016.

Revision received: 31 May 2016.

Accepted for publication: 4 June 2016.

(C) Copyright S. Lombardo et al., 2016

Licensee PAGEPress, Italy

Italian Journal of Agronomy 2016; 11:785

doi:10.4081/ija.2016.785

This article is distributed under the terms of the Creative Commons Attribution Noncommercial License (by-nc 4.0) which permits any noncommercial use, distribution, and reproduction in any medium, provided the original author(s) and source are credited.

\section{Introduction}

Legume seeds provide many of the nutrients required in both the human and animal diet, including protein, starch, mineral elements and vitamins, as well as they contain certain phenolics and oligosaccharides known to be beneficial to health (Crépon et al., 2010). Among legumes, the faba bean (Vicia faba L., sometimes also referred as the broad, horse or field bean) is cultivated for multiple purposes due to both its high nutritional value and adaptability to grow over a wide range of environmental conditions (Sillero et al., 2010). Its global production area in 2012 was around 2.5 Mha, with China and Ethiopia representing the two major producer countries (FA0, 2014). The European contribution to global acreage was only $8.3 \%$ and its production represents $14.4 \%$ of the global figure, but average yield especially in the Mediterranean countries is almost double than somewhere else. Based on a combination of seed weight, shape and size, and end use, the faba bean has been sub-classified into the four botanical varieties paucijuga, major, equina and minor (Cubero, 1974). The former (var. paucijuga) has a short stem, a small number of leaflets per leaf and very small seeds (Cubero, 1974). The broad bean (var. major) produces large, flat seeds, and is consumed as a fresh vegetable, while both the small-seeded field bean (var. minor) and the medium seeded horse bean (var. equina) are used either as green fodder or as a source of dry seeds for feed.

From a nutritional point of view, the improved level of starch and protein in the faba bean seeds, combined with the reduction of certain antinutritional compounds (e.g., vicine and convicine glycosides) which exert a negative effect on animal health, could promote the increased use of this crop in the agro-industrial sector (Crépon et al., 2010; Polignano et al., 2015). In particular, field bean is regarded as a viable replacement for soybean in feed formulations, particularly in market sectors which seek to avoid the inclusion of transgenic material. This, together with the ban of animal proteins in feeding, has led to an increased demand for alternative protein sources, among which field bean (Di Paolo et al., 2015). The latter has also a crucial role on the sustainability of cultivation systems for its effects on soil structure, nitrate leaching, weed competition and pest control (Jensen et al., 2010). However, with the aim to obtain a major diffusion of this crop in the agro-industry, it is essential to find field bean genotypes able to produce acceptable and stable yields also under low input management regime and characterised by qualitative useful traits (Di Paolo et al., 2015). Although much is known regarding the composition and quality of field bean seed (Perella et al., 2009; Crépon et al., 2010), the mineral elements content of the seed has not been extensively studied. This aspect is very relevant since mineral deficiency or imbalance in feed formulations results in depressed animal growth and poor reproductive performance (McDowell, 2003). In addition, since the seed qualitative parameters of faba bean vary with environmental conditions (Musallam et al., 2004; De Vincenzi et al., 2006), it is imperative to study the variation of seed mineral elements composition in relation 
to seasonal climatic conditions. The interaction between climate and genotype should also be taken into account to assess more accurately the environmental adaptation of field bean especially under low management cultivation systems. In this view, the present work was focussed on the assessment of the performance, with respect to both seed mineral elements content and grain yield, of eight field bean genotypes raised, over two consecutive growing seasons, in a typical Mediterranean area for this crop. This may allow to select genotypes showing high yield stability and favourable mineral elements profile, leading to a viable solution to overcame the drastic reduction of field bean production in the area under study.

\section{Materials and methods}

\section{Location, climate and soil of field experiments}

Field experiments were conducted during 2009/10 and 2010/11 growing seasons (hereafter referred to as 2010 and 2011, respectively) at the experimental station of Catania University on the coastal plain of Catania ( $37^{\circ} 30^{\prime} 5^{\prime \prime} \mathrm{N}, 15^{\circ} 4^{\prime} 27^{\prime \prime}$ E, $10 \mathrm{~m}$ a.s.l.), in a Typic and/or Vertic Xerochrepts soil (USDA, 1999). The soil texture, according to the Società Italiana Scienza del Suolo textural classification (SISS, 1985), is clay soil. Soil characteristics, measured at the beginning of the experiments, following approved procedures (SISS, 1985) and referred to a depth of $0-0.40 \mathrm{~m}$, were reported in Table 1 . The local climate is semi-arid-Mediterranean, characterised by mild rainy winters and hot, rainless summers. Specific meteorological conditions across the growing seasons are reported in Figure 1.

\section{Plant material, experimental design and management practices}

Eight field bean genotypes were screened: four Italian commercial cultivars (Scuro di Torre Lama, Chiaro di Torre Lama, Sicania and Sikelia) included in the Italian National Variety Register, one Spanish commercial cultivar (Prothabat 69), two synthetic lines (Sint 6 and Sint 8) and an ecotype (Motta Chiaro 69) selected by Catania University. The constitutor, seed coat colour and flowering time of the selected genotypes are listed in Table 2 . Seed was hand sown, at a depth of $2 \mathrm{~cm}$, in plots $6 \mathrm{~m}$ long $\times 1.5 \mathrm{~m}$ wide at a plant density of 40 -plant $\mathrm{m}^{-2}$ (the row-to-row distance was $0.50 \mathrm{~m}$ and plant-to-plants $0.05 \mathrm{~m}$ ) on 24 November 2009 and 1 December 2010. A randomised block experimental design with four replicates was adopted. Field experiments were carried out under low management regime. The seedbed was prepared using conventional tillage, consisting of $0.4 \mathrm{~m}$ deep ploughing and superficial harrowing. No irrigation, fertilisation or pesticide was applied. Weeds were mechanically controlled by shallow hoeing when plants were at the fourth-eighth-leaf stage. Due to the history of field bean cultivation at this site, the soil has a good Rhyzobium content and therefore seeds were not inoculated.

\section{Phenotypic evaluations}

Flowering time was expressed as the number of days after sowing (DAS) when $50 \%$ of the plants showed full flowering. Grain yield (expressed as tonnes per hectare) was measured by harvesting each plot with a small plot harvester in middle-June. The 1000 seeds weight (expressed as grams) was determined by mixing the whole sample per replicate; thereafter 1000 seeds were randomly counted and weighed.

\section{Chemical analyses}

About 100 seeds per replicate were combined ant then oven-dried at $65^{\circ} \mathrm{C}$ (Binder, Milan, Italy), until a constant weight was reached, in order to determine the dry matter (DM) content. Then, the dehydrated

Table 1. Soil characteristics at the experimental site.

\begin{tabular}{|c|c|}
\hline Soil characteristic & \\
\hline Clay $(<0.002 \mathrm{~mm})^{*}$ & $458 \pm 3$ \\
\hline Silt $(0.02-0.002 \mathrm{~mm})^{*}$ & $365 \pm 3$ \\
\hline Sand $(2-0.02 \mathrm{~mm})^{*}$ & $177 \pm 7$ \\
\hline Total N* & $1.1 \pm 0.01$ \\
\hline Organic matter* & $10.5 \pm 0.7$ \\
\hline $\mathrm{P}_{2} \mathrm{O}_{5}$ available ${ }^{\circ}$ & $12.0 \pm 2.0$ \\
\hline $\mathrm{K}_{2} \mathrm{O}$ exchangeable ${ }^{\circ}$ & $316 \pm 20$ \\
\hline Total $\mathrm{CaCO}_{3}{ }^{*}$ & $90 \pm 4$ \\
\hline Active $\mathrm{CaCO}_{3}{ }^{*}$ & $40 \pm 1$ \\
\hline Electrical conductivity\# & $0.4 \pm 0.03$ \\
\hline $\mathrm{pH}$ & $8.1 \pm 0.04$ \\
\hline Cation exchange capacity§ & $169 \pm 4$ \\
\hline $\mathrm{K}$ exchangeable ${ }^{\circ}$ & $0.7 \pm 0.1$ \\
\hline Mg exchangeable $^{\circ}$ & $3.9 \pm 0.35$ \\
\hline $\mathrm{Ca}$ exchangeable ${ }^{\circ}$ & $11.9 \pm 0.2$ \\
\hline Na exchangeable ${ }^{\circ}$ & $0.6 \pm 0.05$ \\
\hline Fe available $^{\circ}$ & $3.4 \pm 0.2$ \\
\hline Zn available $^{\circ}$ & $4.1 \pm 0.3$ \\
\hline Mn available ${ }^{\circ}$ & $3.3 \pm 0.1$ \\
\hline $\mathrm{Cu}$ available ${ }^{\circ}$ & $0.01 \pm 0.002$ \\
\hline
\end{tabular}

Table 2. Constitutor, seed coat colour, flowering time and 1000 seeds weight of the eight field bean genotypes under study.

\begin{tabular}{|c|c|c|c|c|c|}
\hline Genotype & Constitutor & Type of cultivar & Seed coat colour & $\begin{array}{l}\text { Flowering time } \\
(\mathrm{DAS} \pm \mathrm{SE})\end{array}$ & $\begin{array}{c}1000 \text { seeds weight } \\
(\mathrm{g} \pm \mathrm{SE})\end{array}$ \\
\hline Chiaro di Torre Lama & Napoli University (Italy) & Commercial & Light brown & $111 \pm 2^{\mathrm{a}}$ & $317 \pm 3^{\mathrm{d}}$ \\
\hline Motta Chiaro 69 & Catania University (Italy) & Ecotype & Green & $96 \pm 1^{c}$ & $506 \pm 6^{c}$ \\
\hline Prothabat 69 & Semillas Battle (Spain) & Commercial & Light brown & $108 \pm 2^{b}$ & $501 \pm 3^{c}$ \\
\hline Scuro di Torre Lama & Napoli University (Italy) & Commercial & Black & $108 \pm 2^{b}$ & $308 \pm 2^{\mathrm{d}}$ \\
\hline Sicania & Catania University (Italy) & Commercial & Violet & $91 \pm 3^{c}$ & $533 \pm 4^{\mathrm{ab}}$ \\
\hline Sikelia & Catania University (Italy) & Commercial & Green & $92 \pm 2^{c}$ & $550 \pm 8^{a}$ \\
\hline Sint 6 & Catania University (Italy) & Synthetic line & Green & $95 \pm 2^{c}$ & $528 \pm 11^{\mathrm{bc}}$ \\
\hline Sint 8 & Catania University (Italy) & Synthetic line & Leather brown & $95 \pm 2^{c}$ & $525 \pm 5^{b c}$ \\
\hline
\end{tabular}

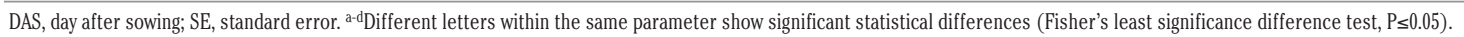


material was ground and passed through a 1-mm sieve, and used for the determination of total nitrogen $(\mathrm{N})$ and macro- and micro-mineral elements profile. In this study, total nitrogen $(\mathrm{N})$ and nine mineral elements [phosphorus $(\mathrm{P})$, potassium $(\mathrm{K})$, magnesium $(\mathrm{Mg})$, calcium (Ca), sodium ( $\mathrm{Na})$, zinc ( $\mathrm{Zn})$, iron (Fe), manganese ( $\mathrm{Mn}$ ) and copper $(\mathrm{Cu})]$ were analysed. An amount $(0.5 \mathrm{~g})$ of dehydrated sample was directly used for total $\mathrm{N}$ determination by using Kjeldhal method. For the analysis of mineral elements, approximately $1 \mathrm{~g}$ of the oven-dried material was put in a muffle furnace at $550 \pm 2^{\circ} \mathrm{C}$ for $24 \mathrm{~h}$. After cooling at room temperature in a desiccator, $\mathrm{P}$ was estimated according to the molybdovanadate colorimetric method 986.24 (AOAC, 1995) using a Shimadzu 1601 UV-Visible spectrometer (Shimadzu Corp., Tokyo, Japan), while the remaining mineral elements (Ca, $\mathrm{Mg}, \mathrm{K}, \mathrm{Na}, \mathrm{Cu}, \mathrm{Fe}$, $\mathrm{Zn}$ and $\mathrm{Mn}$ ) were analysed by atomic absorption spectrometry adopting the AOAC (1995) method 975.03. A Perkin Elmer (Norwalk, USA) AAnalyst 200 atomic absorption spectrometer equipped with a multielement hollow cathode lamp and a deuterium background correction system was used. The total $\mathrm{N}$ content was expressed as \% of DM. The quantification of the other mineral elements in the samples was performed by their calibration curves (AOAC, 1995) and data were expressed as $\mathrm{mg} / \mathrm{kg}$ of DM. All analyses were performed in triplicate.

All the reagents and solvents were purchased from Sigma-Aldrich (Milan, Italy) and were of analytical grade. Bidistilled water was used throughout this research.

\section{Statistical data analysis}

Bartlett's test was used to test for homoscedasticity, following which the data were subjected to a two-way analysis of variance (ANOVA). Means were separated by Fisher's least significant difference test, when the $F$-test was significant. All calculations were performed using SigmaPlot ${ }^{\circledR}$ version 10.0 (Systat Software, Inc., Chicago, IL, USA).

\section{Results}

\section{Seasonal variation in weather}

In 2010, the precipitation experienced from November to June was $195 \mathrm{~mm}$ less than in 2011 (Figure 1), and most of it fell between November and March, resulting in a dry end to the growing season. The distribution of rainfall was more regular in 2011, only with a peak (160 $\mathrm{mm}$ ) in February. Mean values of air temperatures were quite similar between the two years (Figure 1), and no occurrences of frost were recorded in either year.

\section{Phenotypic variation}

Seed coat colour varied from black (Scuro di Torre Lama) to light brown (Chiaro di Torre Lama and Prothabat 69) and from violet (Sicania) to green (Sikelia, Motta Chiaro 69 and Sint 6) (Table 2), while flowering time ranged from 91 days (Sicania) to 111 days (Chiaro di Torre Lama) (Table 2). The 1000 seeds weight was a characteristic of each genotype and largely unaffected by the year (Table 2). The highest value was reported by Sikelia and Sicania, followed by Sint 6 and Sint 8; one thousand seeds of Chiaro di Torre Lama and Scuro di Torre Lama weighed only $312 \mathrm{~g}$ (Table 2 ). Grain yield was significantly affected by genotype $\times$ year interaction (Table 3 ). Apart from Chiaro di Torre Lama, grain yield was higher in 2011 than in 2010 (Figure 2). In particular, the yield variation between years was 70\% for Scuro di Torre Lama and 77\% for Sikelia. The grain yields of Sicania and Motta Chiaro 69 were also year-dependent, in contrast to that of Chiaro di Torre Lama (Figure 2).

\section{Total nitrogen, macro- and micro-mineral elements profile}

The genotype $\times$ year interaction component of the variance was significant, except in the case of total $\mathrm{N}$ content (Table 3). The latter ranged from 3.8\% (Motta Chiaro 69, Sint 6 and Scuro di Torre Lama) to $4.1 \%$ (Prothabat 69 ) on a DM basis (Figure 3). The seasonal differ-

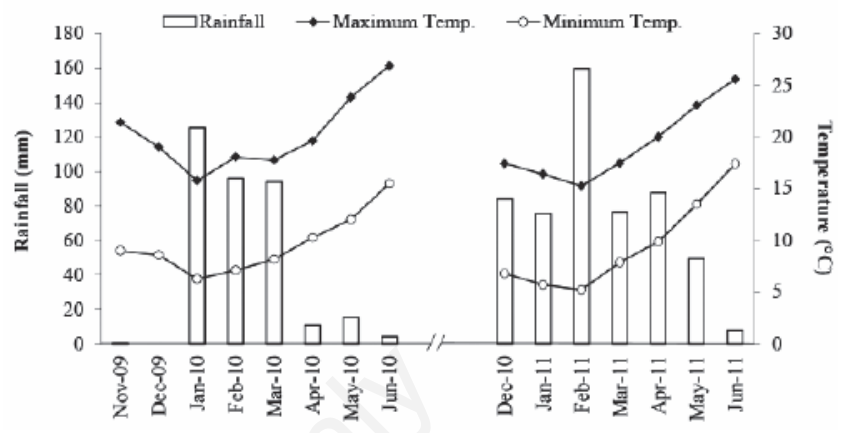

Figure 1. Average monthly maximum and minimum temperatures and total monthly rainfall during the two growing seasons at the experimental site.

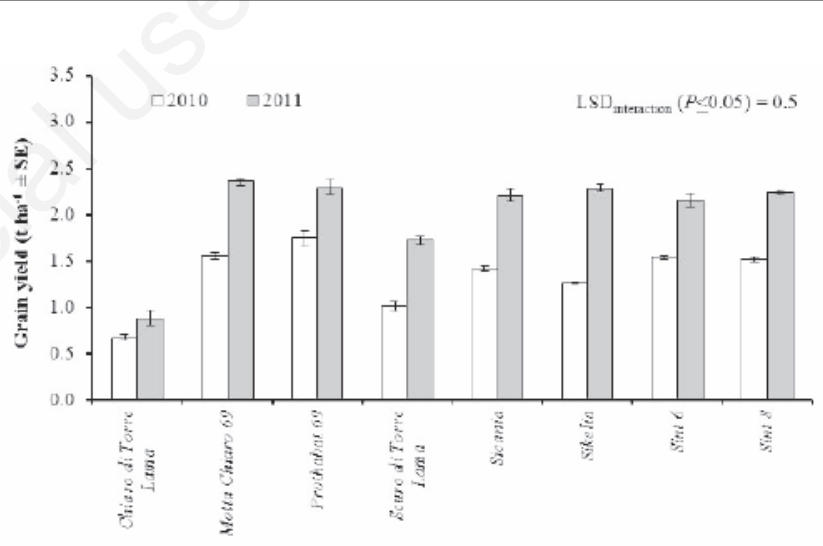

Figure 2. Grain yield of field bean as affected by genotype $\times$ year interaction [Fisher's least significant difference (LSD) test, $P \leq 0.05]$. Vertical bars $=\mathrm{SE}$, standard error.

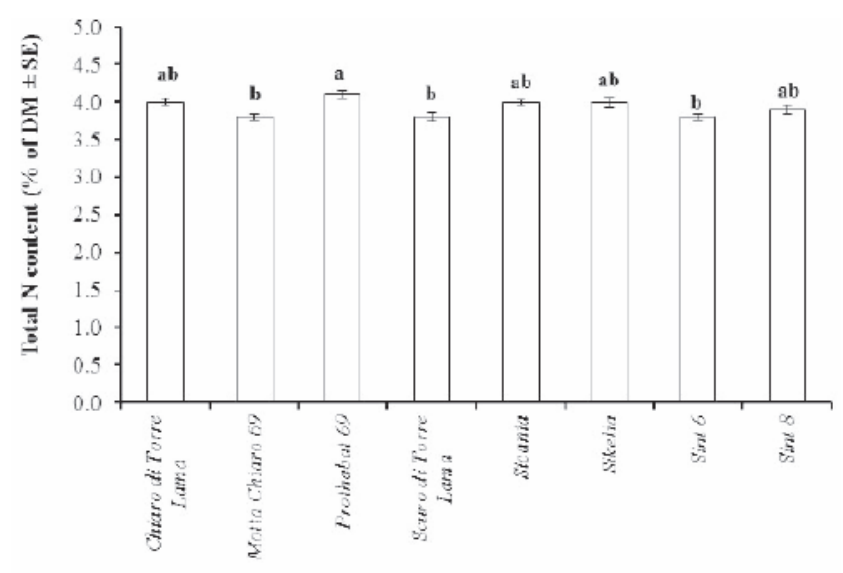

Figure 3. Total nitrogen $(\mathrm{N})$ content of field bean seed as affected by genotype. Different letters indicate significant statistical differences [Fisher's least significant difference (LSD) test, $P \leq 0.05$ ]. $\mathrm{DM}$, dry matter; Vertical bars $=\mathrm{SE}$, standard error. 
ences for the other seed mineral elements were not uniform across all the genotypes (Tables 4 and 5). For instance, three of the eight genotypes accumulated a similar level of $\mathrm{Ca}$ in the two years, whereas in the other five the Ca content was higher in 2011, with Sikelia achieving the highest differential (+36\%) (Table 4). While Mg and Na contents were generally higher in 2011, this did not apply to either Scuro di Torre Lama or Prothabat 69. Scuro di Torre Lama seed also accumulated less
$\mathrm{K}$ in 2011 than in 2010, while the opposite was true for the other seven genotypes. Likewise, Sicania, Sikelia and Sint 8 seed had higher P contents in 2011, whereas those of Chiaro di Torre Lama, Motta Chiaro 69 and Sint 6 all decreased ( $-46 \%$, on average; Table 4$)$. The concentration in the seed of all the micro-mineral elements was generally higher in the 2010 than in the 2011 harvest (Table 5). With reference to the results reported in 2010, the Fe content of Sint 6 and Sikelia seed

Table 3. P-values, mean square as absolute value and percentage of total (in brackets), resulting from analysis of variance, for all the studied variables.

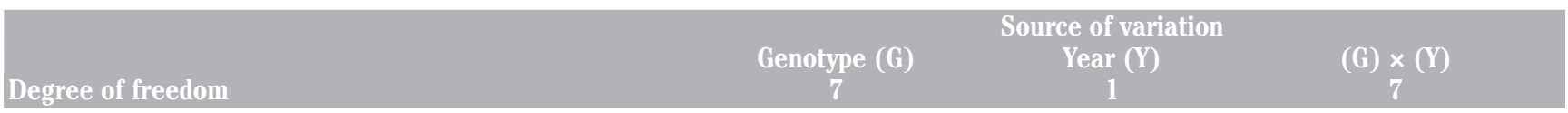

Variable

\begin{tabular}{|c|c|c|c|c|}
\hline Flowering time & $\begin{array}{l}\text { MS } \\
\text { P-value }\end{array}$ & $\begin{array}{c}530(86.1) \\
<0.0001\end{array}$ & $\begin{array}{c}81(13.1) \\
0.0640\end{array}$ & $\begin{array}{c}3.3(0.1) \\
0.1620\end{array}$ \\
\hline 1000 seeds weight & $\begin{array}{l}\text { MS } \\
\text { P-value }\end{array}$ & $\begin{array}{c}782,363(99.7) \\
<0.0001\end{array}$ & $\begin{array}{c}505(0.1) \\
0.2337\end{array}$ & $\begin{array}{c}1680(0.2) \\
0.1340\end{array}$ \\
\hline Grain yield & $\begin{array}{l}\text { MS } \\
\text { P-value }\end{array}$ & $\begin{array}{l}1.4(15.7) \\
<0.0001\end{array}$ & $\begin{array}{c}7.4(83.1) \\
<0.0001\end{array}$ & $\begin{array}{l}0.1(1.1) \\
<0.0001\end{array}$ \\
\hline Total N & $\begin{array}{l}\text { MS } \\
\text { P-value }\end{array}$ & $\begin{array}{c}0.048(53.3) \\
0.0143\end{array}$ & $\begin{array}{c}0.025(27.8) \\
0.2120\end{array}$ & $\begin{array}{c}0.016(17.8) \\
0.4332\end{array}$ \\
\hline$P$ & $\begin{array}{l}\text { MS } \\
\text { P-value }\end{array}$ & $\begin{array}{c}8,108,816(57.6) \\
<0.0001\end{array}$ & $\begin{array}{l}1,908,081(13.6) \\
<0.0001\end{array}$ & $\begin{array}{c}4,042,925(28.7) \\
<0.0001\end{array}$ \\
\hline K & $\begin{array}{l}\text { MS } \\
\text { P-value }\end{array}$ & $\begin{array}{c}30,604(4.8) \\
<0.0001\end{array}$ & $\begin{array}{c}542,101(85.4) \\
<0.0001\end{array}$ & $\begin{array}{c}61,371(9.7) \\
<0.0001\end{array}$ \\
\hline $\mathrm{Mg}$ & $\begin{array}{l}\text { MS } \\
\text { P-value }\end{array}$ & $\begin{array}{l}163,741(25.2) \\
\quad<0.0001\end{array}$ & $\begin{array}{l}312,643(48.1) \\
\quad<0.0001\end{array}$ & $\begin{array}{c}171,135(26.3) \\
\quad<0.0001\end{array}$ \\
\hline $\mathrm{Ca}$ & $\begin{array}{l}\text { MS } \\
\text { P-value }\end{array}$ & $\begin{array}{c}34,881(16.7) \\
<0.0001\end{array}$ & $\begin{array}{c}132,098(63.2) \\
<0.0001\end{array}$ & $\begin{array}{c}39,027(18.7) \\
<0.0001\end{array}$ \\
\hline $\mathrm{Na}$ & $\begin{array}{l}\text { MS } \\
\text { P-value }\end{array}$ & $\begin{array}{l}233(3.0) \\
<0.0001\end{array}$ & $\begin{array}{c}6862(88.3) \\
<0.0001\end{array}$ & $\begin{array}{l}669(8.6) \\
<0.0001\end{array}$ \\
\hline $\mathrm{Fe}$ & $\begin{array}{l}\text { MS } \\
\text { P-value }\end{array}$ & $\begin{array}{l}390(5.9) \\
<0.0001\end{array}$ & $\begin{array}{l}6053(91.2) \\
<0.0001\end{array}$ & $\begin{array}{c}180(2.7) \\
0.0178\end{array}$ \\
\hline Zn & $\begin{array}{l}\text { MS } \\
\text { P-value }\end{array}$ & $\begin{array}{l}25(3.1) \\
<0.0001\end{array}$ & $\begin{array}{c}733(92.3) \\
<0.0001\end{array}$ & $\begin{array}{l}36(4.5) \\
<0.0001\end{array}$ \\
\hline $\mathrm{Cu}$ & $\begin{array}{l}\text { MS } \\
\text { P-value }\end{array}$ & $\begin{array}{l}7(0.2) \\
0.2500\end{array}$ & $\begin{array}{c}4046(99.4) \\
<0.0001\end{array}$ & $\begin{array}{c}15(0.4) \\
0.0090\end{array}$ \\
\hline $\mathrm{Mn}$ & $\begin{array}{l}\text { MS } \\
\text { P-value }\end{array}$ & $\begin{array}{c}0.3(0.1) \\
0.6426\end{array}$ & $\begin{array}{c}274(99.5) \\
<0.0001\end{array}$ & $\begin{array}{c}1.1(0.4) \\
0.0409\end{array}$ \\
\hline
\end{tabular}

MS, mean square; N, nitrogen; P, phosphorus; K, potassium; Mg, magnesium; Ca, calcium; Na, sodium; Fe, iron; Zn, zinc; Cu, copper; Mn, manganese.

Table 4. Macro-mineral elements profile $(\mathrm{mg} / \mathrm{kg}$ of dry matter \pm standard error) of field bean seeds as affected by genotype $\times$ year interaction.

\begin{tabular}{|c|c|c|c|c|c|c|c|c|c|c|}
\hline \multirow[t]{2}{*}{ Genotype } & \multicolumn{2}{|c|}{$\mathbf{P}$} & \multicolumn{2}{|c|}{$\mathrm{K}$} & \multicolumn{2}{|c|}{$\mathrm{Mg}$} & \multicolumn{2}{|c|}{$\mathrm{Ca}$} & \multicolumn{2}{|c|}{$\mathrm{Na}$} \\
\hline & 2010 & 2011 & 2010 & 2011 & 2010 & 2011 & 2010 & 2011 & 2010 & 2011 \\
\hline Chiaro di Torre Lama & $7793 \pm 136$ & $3643 \pm 75$ & $2361 \pm 10$ & $2144 \pm 20$ & $2681 \pm 18$ & $2999 \pm 18$ & $1588 \pm 18$ & $1710 \pm 15$ & $45.0 \pm 1.2$ & $77.2 \pm 2.4$ \\
\hline Motta Chiaro 69 & $3100 \pm 50$ & $1702 \pm 131$ & $2237 \pm 20$ & $2164 \pm 18$ & $1894 \pm 38$ & $2819 \pm 30$ & $1588 \pm 18$ & $1572 \pm 13$ & $45.1 \pm 1.8$ & $79.9 \pm 1.0$ \\
\hline Prothabat 69 & $5382 \pm 42$ & $4870 \pm 20$ & $2688 \pm 20$ & $2039 \pm 17$ & $2279 \pm 50$ & $2268 \pm 80$ & $1461 \pm 22$ & $1597 \pm 16$ & $85.5 \pm 2.3$ & $54.7 \pm 0.6$ \\
\hline Scuro di Torre Lama & $2044 \pm 89$ & $1735 \pm 85$ & $2265 \pm 14$ & $2454 \pm 22$ & $2965 \pm 20$ & $2468 \pm 47$ & $1380 \pm 24$ & $1390 \pm 10$ & $34.5 \pm 1.1$ & $59.5 \pm 0.8$ \\
\hline Sicania & $1244 \pm 70$ & $3068 \pm 12$ & $2458 \pm 18$ & $2213 \pm 20$ & $2280 \pm 16$ & $2349 \pm 20$ & $1365 \pm 15$ & $1399 \pm 5$ & $45.8 \pm 1.2$ & $87.8 \pm 0.4$ \\
\hline Sikelia & $2694 \pm 43$ & $4550 \pm 177$ & $2623 \pm 14$ & $2184 \pm 17$ & $2189 \pm 38$ & $2717 \pm 20$ & $1275 \pm 20$ & $1735 \pm 10$ & $41.3 \pm 1.2$ & $96.5 \pm 2.2$ \\
\hline Sint 6 & $4625 \pm 13$ & $2758 \pm 268$ & $2595 \pm 21$ & $2265 \pm 12$ & $2504 \pm 30$ & $2653 \pm 31$ & $1268 \pm 22$ & $1595 \pm 10$ & $41.7 \pm 2.0$ & $82.5 \pm 1.9$ \\
\hline Sint 8 & $4242 \pm 94$ & $4891 \pm 312$ & $2369 \pm 18$ & $2051 \pm 20$ & $2559 \pm 20$ & $2665 \pm 47$ & $1365 \pm 15$ & $1593 \pm 8$ & $38.6 \pm 1.9$ & $73.0 \pm 3.6$ \\
\hline LSD interaction $(\mathrm{P} \leq 0.0$ & & & & & & & & & & \\
\hline
\end{tabular}

P, phosphorus; K, potassium; Mg, magnesium; Ca, calcium; Na, sodium. *Fisher's least significant difference (LSD) test, P $\leq 0.05$. 
decreased more sharply in 2011 than did that of the other six genotypes ( $-62 \%$ and $-55 \%$, respectively), while the $\mathrm{Cu}$ content of Motta Chiaro 69 and Sint 8 seed was more sensitive than that of the other genotypes ( $-75 \%$ and $-69 \%$, respectively). The Mn and Zn contents of Motta Chiaro 69 seed responded most acutely to the year (Table 5).

\section{Trait correlations}

Grain yield was positively correlated $\left(\mathrm{r}=+0.619^{*}\right)$ with 1000 seeds weight, and negatively $(\mathrm{r}=-0.542 *)$ with flowering time (data not shown). The latter trait was also negatively correlated $\left(\mathrm{r}=-0.806^{*}\right)$ with 1000 seeds weight. There were no significant correlations observed between either yield or 1000 seeds weight and any of the mineral elements content (data not shown). Seed K content was positively correlated with those of both $\mathrm{Mn}\left(\mathrm{r}=+0.665^{* *}\right)$ and $\mathrm{Cu}\left(\mathrm{r}=+0.649^{* *}\right)$, while being negatively correlated with that of $\mathrm{Ca}\left(\mathrm{r}=-0.505^{*}\right)$ (Table $6)$. Na content was positively correlated with that of $\mathrm{Ca}\left(\mathrm{r}=+0.668^{* *}\right)$, but negatively with those of $\mathrm{Mn}$ and $\mathrm{Cu}\left(\mathrm{r}=-0.764^{* * *}\right.$ and $-0.754^{* * *}$, respectively), as well as with those of $\mathrm{Fe}$ and $\mathrm{Zn}\left(\mathrm{r}=-0.596^{*}\right.$ and $0.590^{*}$, respectively). Zn content was positively correlated with those of all the other micro-mineral elements, but negatively with that of $\mathrm{Mg}$ $\left(\mathrm{r}=-0.610^{*}\right) . \mathrm{Cu}$ and $\mathrm{Mn}$ content were both positively correlated with that of $\mathrm{Fe}\left(\mathrm{r}=+0.776^{* * *}\right.$ and $+0.783^{* * *}$, respectively). In addition, the seed $\mathrm{Cu}$ content was positively correlated with that of $\mathrm{Mn}(\mathrm{r}=$ $\left.+0.983^{* * *}\right)($ Table 6$)$.

\section{Discussion}

For field bean production to be encouraged in the Mediterranean environment, it will be necessary to derive genotypes, which yield stably (Avola et al., 2008) and produce seed, which is nutritionally relevant for animal feed formulations (McDowell, 2003). Under a productive standpoint, six of the eight genotypes under study well performed under low management regime, as compared to the results reported under conventional management systems (Loss et al., 1997). However, weather conditions (mainly rainfall amount and distribution) significantly influenced yield of field bean. Although all eight genotypes studied here were more productive in the second year than in the first (largely attributable to differences in moisture availability), the response was most acute for Scuro di Torre Lama, Sikelia and Sicania. Four of the eight genotypes (Motta Chiaro 69, Prothabat 69, Sint 6 and Sint 8 ) maintained an appreciable yield level (sometimes higher than that detected for the reference commercial cultivars Scuro di Torre Lama and Chiaro di Torre Lama) in the less favourable growing season. This is encouraging in the context of the need to breed genotypes adapted to a low rainfall environment, typical of marginal areas of Mediterranean Basin (Loss et al., 1997), and to low management cultivation systems.

Likewise the content of mineral elements in field bean seeds was

Table 5. Micro-mineral elements profile ( $\mathrm{mg} / \mathrm{kg}$ of dry matter \pm standard error) of field bean seeds as affected by genotype $x$ year interaction.

\begin{tabular}{|c|c|c|c|c|c|c|c|c|}
\hline \multirow[t]{2}{*}{ Genotype } & \multicolumn{2}{|c|}{$\mathrm{Fe}$} & \multicolumn{2}{|c|}{$\mathrm{Zn}$} & \multicolumn{2}{|c|}{$\mathrm{Cu}$} & \multicolumn{2}{|c|}{$\mathbf{M n}$} \\
\hline & 2010 & 2011 & 2010 & 2011 & 2010 & 2011 & 2010 & 2011 \\
\hline Chiaro di Torre Lama & $94.3 \pm 3.0$ & $49.5 \pm 1.0$ & $37.5 \pm 0.3$ & $23.6 \pm 1.2$ & $36.9 \pm 0.9$ & $13.4 \pm 0.4$ & $12.2 \pm 0.8$ & $6.4 \pm 0.2$ \\
\hline Motta Chiaro 69 & $65.2 \pm 1.0$ & $38.9 \pm 1.5$ & $47.9 \pm 0.6$ & $26.5 \pm 0.1$ & $35.1 \pm 1.8$ & $8.7 \pm 0.7$ & $12.7 \pm 0.3$ & $5.9 \pm 0.4$ \\
\hline Prothabat 69 & $60.1 \pm 4.1$ & $32.9 \pm 0.5$ & $38.7 \pm 0.6$ & $32.3 \pm 1.2$ & $32.9 \pm 0.1$ & $13.9 \pm 0.2$ & $11.2 \pm 0.4$ & $6.9 \pm 0.2$ \\
\hline Scuro di Torre Lama & $51.1 \pm 2.0$ & $35.9 \pm 1.5$ & $38.0 \pm 0.3$ & $30.6 \pm 0.6$ & $35.6 \pm 0.4$ & $14.8 \pm 0.9$ & $11.1 \pm 0.3$ & $6.9 \pm 0.1$ \\
\hline Sicania & $54.1 \pm 3.1$ & $31.4 \pm 1.1$ & $37.2 \pm 0.3$ & $34.0 \pm 1.7$ & $36.4 \pm 2.2$ & $12.5 \pm 0.4$ & $12.2 \pm 0.2$ & $5.8 \pm 0.3$ \\
\hline Sikelia & $83.2 \pm 8.0$ & $32.9 \pm 1.9$ & $32.5 \pm 0.6$ & $28.3 \pm 0.6$ & $34.2 \pm 0.4$ & $13.0 \pm 0.7$ & $12.7 \pm 0.2$ & $6.9 \pm 0.4$ \\
\hline Sint 6 & $62.1 \pm 6.1$ & $23.8 \pm 1.6$ & $41.3 \pm 1.1$ & $28.8 \pm 0.5$ & $32.5 \pm 0.6$ & $11.2 \pm 0.2$ & $12.3 \pm 0.8$ & $5.8 \pm 0.2$ \\
\hline Sint 8 & $59.1 \pm 5.5$ & $54.0 \pm 1.5$ & $36.3 \pm 0.4$ & $28.3 \pm 0.4$ & $34.7 \pm 0.4$ & $10.8 \pm 0.4$ & $12.7 \pm 0.3$ & $5.8 \pm 0.4$ \\
\hline LSD interaction $(\mathrm{P} \leq 0.05)^{*}$ & \multicolumn{2}{|c|}{15.1} & \multicolumn{2}{|c|}{2.4} & \multicolumn{2}{|c|}{2.4} & \multicolumn{2}{|c|}{1.3} \\
\hline
\end{tabular}

Fe, iron; Zn, zinc; Cu, copper; Mn, manganese. *Fisher's least significant difference (LSD) test, $\mathrm{P} \leq 0.05$.

Table 6. Pearson's correlation coefficients and significance of correlations among all the mineral elements analysed at seeds harvesting along the two-years experiment.

\begin{tabular}{|c|c|c|c|c|c|c|c|c|c|c|}
\hline & Total N & $\mathbf{P}$ & $\mathrm{K}$ & $\mathrm{Mg}$ & $\mathrm{Ca}$ & $\mathrm{Na}$ & $\mathrm{Fe}$ & $\mathrm{Zn}$ & $\mathrm{Cu}$ & Mn \\
\hline Total N & - & & & & & & & & & \\
\hline$P$ & NS & - & & & & & & & & \\
\hline K & NS & NS & - & & & & & & & \\
\hline $\mathrm{Mg}$ & NS & NS & NS & - & & & & & & \\
\hline $\mathrm{Ca}$ & NS & NS & $-0.505^{*}$ & NS & - & & & & & \\
\hline $\mathrm{Na}$ & NS & NS & NS & NS & $0.668^{* *}$ & - & & & & \\
\hline $\mathrm{Fe}$ & NS & NS & NS & NS & NS & $-0.596 *$ & - & & & \\
\hline Zn & NS & NS & NS & $-0.610^{*}$ & NS & $-0.590^{*}$ & $0.516^{*}$ & - & & \\
\hline $\mathrm{Cu}$ & NS & NS & $0.649 * *$ & NS & NS & $-0.754 * * *$ & $0.776 * * *$ & $0.796 * * *$ & - & \\
\hline $\mathrm{Mn}$ & NS & NS & $0.665^{* *}$ & NS & NS & $-0.764^{* * *}$ & $0.783^{* * *}$ & $0.790^{* * *}$ & $0.983^{* * *}$ & - \\
\hline
\end{tabular}

$\mathrm{N}$, nitrogen; P, phosphorus; K, potassium; Mg, magnesium; Ca, calcium; Na, sodium; Fe, iron; Zn, zinc; Cu, copper; Mn, manganese; NS, not significant. *,** and *** indicate significant at P $\leq 0.05$, P $\leq 0.01$ and $\mathrm{P} \leq 0.001$, respectively. 
heavily influenced by the year, with $\mathrm{Mg}, \mathrm{Ca}$ and $\mathrm{Na}$ contents being generally higher in 2011 than in 2010, and the reverse for the other mineral elements. A possible explanation includes different rooting depths in the two years and a possible dilution effect. In 2010 (with lower precipitation) the roots likely penetrated greater depths to find water, and they proliferated in deeper soil horizons which probably have different concentrations of mineral elements than the topsoil, while in 2011 (with more moisture) the roots were more active in the topsoil and interacted with the mineral elements contained in this horizon. Overall, the highest $P$ seed level in 2010 was probably due to the role of such mineral element in the drought resistance (Jensen et al., 2010). A reason for the greater content of $\mathrm{Mg}, \mathrm{Ca}$ and $\mathrm{Na}$ in 2011 may rest in the antagonistic/synergistic interrelationships they have with other cations in the soil. In particular, $\mathrm{K}$ is a well-known strong antagonist of $\mathrm{Mg}, \mathrm{Ca}$ and $\mathrm{Na}$, whose increased content in 2011 may be therefore imputed to a lower depressing effect of $\mathrm{K}$ (due to higher $\mathrm{K}$ mobility under rainfed conditions) on the plant uptake of such mineral elements. Moreover, in this study Ca seed levels were positively correlated with those of $\mathrm{Na}$, which in turn were negatively correlated with those of the micro-mineral elements analysed (which were all accumulated less effectively in 2011). Similarly Fageria and Baligar (1999) reported a decrease in $\mathrm{Zn}, \mathrm{Mn}$ and $\mathrm{Fe}$ in wheat and soybean plants with increasing $\mathrm{Ca}$ uptake. Likewise $\mathrm{Mg}$ content was negatively correlated with that of $\mathrm{Zn}$, the accumulation of which was favoured in 2011. However, the studied genotypes differed in their response to seasonal conditions in terms of mineral elements content. As an instance, passing from 2010 to 2011 Sint 6 and Sikelia reported the highest decrease $(-62 \%$ and $55 \%$, respectively) for the Fe content, while the latter did not vary for Sint 8 . This is relevant under a nutritional perspective, since highlighted that some genotypes may accumulate a certain nutrient in the seed also in presence of a nutrient deficiency in the soil (for example due to a dilution effect) (Bonfil and Kakafi, 2000).

Our study also pointed out that $\mathrm{P}$ levels were typically higher than those of $\mathrm{K}$, a result that is inconsistent with the general observation that in grain legume seeds $\mathrm{K}$ content tends to be higher than that of $\mathrm{P}$ (Hacısefero ulları et al., 2003; Özcan et al., 2013; Di Paolo et al., 2015). The differences with the literature data may be ascribable to the different environmental conditions (in terms of soil mineral elements composition and climate) experienced in our field trials. Our finding may have also resulted from the influence of rhizosphere bacteria by changing the root-uptake characteristics and the redistribution of minerals within the plant organs (Rodelas et al., 1999). Our result is, however, of some interest, since the P content of forage is typically very low (Pinchak et al., 1989) and, therefore, some supplementation of this mineral element may be required in the formulation of a balanced animal diet. The seed Mg and Ca contents of the eight field bean genotypes were generally higher than those reported in broad bean (Hacisefero ulları et al., 2003), probably due to the favourable soil $\mathrm{Ca}: \mathrm{Mg}$ ratio. Na was the least accumulated of the macro-mineral elements, as has previously been noted in other grain legumes (Iqbal et $a l ., 2006)$. In agreement with the literature (Hacısefero ullarl et al., 2003; Özcan et al., 2013), Fe was the most abundant micro-mineral elements present in the field bean seed. Compared with other grain legume crops (Iqbal et al., 2006; Özcan et al., 2013), the field bean seed is an effective accumulator of $\mathrm{Cu}$. Ratios between the content of some mineral elements is significant in the context of nutrition. As an instance, the $\mathrm{Na} / \mathrm{K}$ ratio in the seed of the eight field bean genotypes (about 0.03) was much lower than that present in other grain legume seed (Iqbal et al., 2006). This parameter is important for managing risk with respect to high blood pressure and certain cardiovascular diseases (Pandino et al., 2011). In addition, the studied field bean genotypes had a Ca:P ratio <1, which is considered to be appropriate for the optimal absorption of both mineral elements (McDowell, 2003).
In conclusion, the present work has demonstrated the possibility of obtaining acceptable grain yields from field bean even under a low management cultivation regime. Moreover, the genotypes under study would offer producers a real advantage in terms of nutritional performance in animals' diet, having a good seed mineral elements composition. Particularly, Chiaro di Torre Lama accumulated more $\mathrm{P}, \mathrm{Mg}, \mathrm{Ca}$ and Fe than did any of the other genotypes, while Sint 6 and Motta Chiaro 69 were the most effective accumulators of $\mathrm{K}$ and $\mathrm{Zn}$, respectively. For $\mathrm{Na}$, the most efficient absorber was Prothabat 69 , a genotype that also produced the seed richest in total N. However, the seasonal climatic conditions were determinant in the yielding ability and the determination of mineral elements profile. This implies that further researches are still required to assess the yield and nutritive potentialities of the selected genotypes in other environments (different in soil and climatic conditions) as well as to evaluate the effect of a high ratio of field bean seeds in livestock diets.

\section{References}

AOAC, 1995. Official methods of analysis. Association of Official Analytical Chemists, Washington, DC, USA.

Avola G, Tuttobene R, Gresta F, Abbate V, 2008. Weed control strategies for grain legumes. Agron. Sustain. Dev. 28: 339-95.

Bonfil DJ, Kakafi U, 2000. Wild wheat adaptation in different soil ecosystems as expressed in the mineral concentration of the seeds. Euphytica 114:123-34.

Crépon K, Marget P, Peyronnet C, Carrouée B, Arese P, Duc G, 2010. Nutritional value of faba bean (Vicia faba L.) seeds for feed and food. Field Crop. Res. 115: 329-39.

Cubero JI, 1974. On the evolution of Vicia faba L.. Theoret. Appl. Genet. 45:47-51.

De Vincenzi S, Lupattelli M, Cestola E, Lipioni GB, 2006. Effect of variety and agronomical conditions on the level of polyphenols and antinutritional factors of Vicia faba minor. Vet. Res. Commun. 30:371-4.

Di Paolo E, Garofalo P, Rinaldi M, 2015. Irrigation and nitrogen fertilisation treatments on productive and qualitative traits of broad bean (Vicia faba var. minor L.) in a Mediterranean environment. Legume Res. 38: 209-18.

Fageria NK, Baligar VC, 1999. Growth and nutrient concentration of common bean, lowland rice, corn, soybean, and wheat at different soil pH on an inceptisol. J. Plant Nutr. 22:1495-507.

FA0, 2014. Statistical database. Available from: http:/www.faostat.org/

Hacisefero ullari H, Gezer I, Bahtiyarca Y, Menge HO, 2003. Determination of some chemical and physical properties of Sakız faba bean (Vicia faba L. var. major). J. Food Eng. 60:475-9.

Iqbal A, Khalil IA, Ateeq N, Khan MS, 2006. Nutritional quality of important food legumes. Food Chem. 97:331-5.

Jensen ES, Peoples MB, Hauggaard-Nielsen H, 2010. Faba bean in cropping systems. Field Crops Res. 115:203-16.

Loss SP, Siddique KHM, Tennant D, 1997. Adaptation of faba bean (Vicia faba L.) to dryland Mediterranean-type environments. III. Water use and water-use efficiency. Field Crop. Res. 54:153-62.

Mc Dowell LR, 2003. Minerals in animal and human nutrition. Elsevier, Amsterdam, Netherlands.

Musallam IW, Al-Karaki GN, Ereifej KI, Tawaha Abdel-Rahman M, 2004. Chemical composition of faba bean genotypes under rainfed and irrigation conditions. Int. J. Agri. \& Biol. 6:359-362.

Özcan MM, Dursun N, Juhaimi A, 2013. Macro- and microelement contents of some legume seeds. Environ. Monit. Assess. 185:9295-8.

Pandino G, Lombardo S, Mauromicale G, 2011. Mineral profile in globe 
artichoke as affected by genotype, head part and environment. J. Sci. Food Agric. 91:302-8.

Perella F, Mugnai C, Dal Bosco A, Sirri F, Cestola E, Castellini C, 2009. Faba bean (Vicia faba var. minor) as a protein source for organic chickens: performance and carcass characteristics. Ital. J. Anim. Sci. 8:575-84.

Pinchak WE, Green LW, Heitschmidt RK, 1989. Mineral dynamics in beef cattle diets from a southern mixed-grass prairie. J. Range Manage. 42:431-3.

Polignano GB, Bisignano V, Alba V, 2015. Two field bean (Vicia faba L. var. minor Peterm.) breeding selections for a potential agronomic and industrial use. Genet. Resour. Crop. Evol. 62:971-7.
Rodelas B, González-López J, Martínez-Toledo MV, Pozo C, Salmerón V, 1999. Influence of Rhizobium/Azotobacter and Rhizobium/ Azospirillum combined inoculation on mineral composition of faba bean (Vicia faba L.). Biol. Fertil. Soils 29:165-9.

Sillero JC, Villegas-Fernàndez AM, Thomas J, Rojas-Molina MM, Emeran AA, Fernàndez-Aparicio M, Rubiales D, 2010. Faba bean breeding for disease resistance. Field Crop Res. 115:297-307.

SISS (Società Italiana Scienza del Suolo), 1985. Metodi normalizzati di analisi del suolo. Edagricole, Bologna, Italy.

USDA-NRCS, 1999. USDA-NRCS soil taxonomy, a basic system of soil classification for making and interpreting soil surveys. U.S. Government Printing Office, Washington, DC, USA. 